\title{
Investigation of Self-Regulated Learning Abilities of College Students
}

\author{
Meryem ÖZTURAN SAĞIRLI* \\ Esra AZAPAĞASI ${ }^{* *}$
}

\begin{abstract}
The purpose of this study is to determine if university students are using their self-regulation capabilities or not and to learn which methods students use to arrange their selfregulation capabilities. A qualitative study was conducted in which, individual and focus group interviews were used to collect. The analysis of the data was handled by using NVivo program. The results showed that students more likely to use self-regulation capabilities such as metacognitive self-regulation, the time / study environmental management, rehearsal, elaboration, peer learning, organization and help seeking, critical thinking and effort regulation; in motivation category, test anxiety, control of learning beliefs, self efficacy, intrinsic goal orientation, extrinsic goal orientation and task value were categories seen in motivation domain.
\end{abstract}

Key words: Self -regulated learning, learning strategies, motivation

${ }_{\star *}^{*}$ Research Assist. , Erzincan University, Faculty of Education, msagirli@erzincan.edu.tr Atatürk University, Institute of Science, eses_asra@hotmail.com 


\section{SUMMARY}

Purpose and Significance: The purpose of this study is to determine whether university students are using their self-regulation capabilities or not and to learn which methods students use to arrange their self-regulation capabilities. Many definitions are made regarding self-regulation, and the conceptual frame of the selfregulation subject is taken into consideration with different titles. In this article, the limits of the self-regulation subject are studied with Pintrich and De Groot's (1990) header and footers in motivated strategies for learning qestionnaire.

Methods: This study was conducted in the direction of qualitative research approach and descriptive analysis is made. The class academic averages of the 19 student participants were taken from 3 different levels, low, medium and high. Individual interviews and focus group interviews were used as data collection methods. Semi configured survey form was used in both interviews. The draft of this form was prepared in order to question the answers of headers and footers in motivating strategies scale. In this study, the metacognitive self-regulation, the time / study environmental management, rehearsal, elaboration, peer learning, organizing, help seeking, critical thinking and effort regulation sub titles correspond to codes while motivation and learning strategies which are the headers correspond to categories. Our theme is self regulated learning.

Results: In the learning strategies category, the most used code consists of over-cognition self-regulation and arranging the time / study environment with 18 opinions, repeating follows with 17 and elaboration code follows with 16 opinions. 14 opinions were for 1 peer learning, 10 opinions were from organizing and seeking help and 6 opinions were from effort regulation. Total opinions about this category were 117. In motivation category, most opinions (13) were given for test anxiety code. This is followed by controlling learning beliefs with 14 opinions, self efficacy with 12 opinions, extrinsic goal orientation with 10 opinions. After those, comes the instrinsic goal orientation with 10 opinions, extrinsic goal orientation with 3 opinions and task value with 1 opinion. Total opinions about this category were 57.

Discussion and Conclusions: The learning strategies in high education are used actively by students. The opinions in metacognitive self-regulation code and time / study environmental management control code being a lot, means that students are aware of their features and are good self-regulator. Although students use the motivation category actively too, it is understood from the opinions about extrinsic goal orientation and task value codes, students are not paying enough attention to R\&D activities. Considering the expectations of high education from the students, there are very few opinions under the scope of this code. This situation will partially affect the efforts of students for being good self-regulators.

Convincing the students to be good self-regulators, to let them realize the methods to become good self-regulators and to let them be aware of their selfregulation capabilities, will certainly increase the quality of the education. The quality of the education activities will also increase and students with self-regulation which are the necessity of the information age that we are living, will continue to be educated. Regarding the learning of Self-regulation, although many researchers have been made in our country and in the world, most of these researches are limited with quantitative methodologies. Using qualitative methodologies in the researches to be made will bring a new expansion to the learning of self-regulation. The differences of the students in means of self regulation according to their sex, graduated high school and the discipline they are being educated may create new subject areas that will be studied with qualitative approaches. 


\title{
Üniversite Öğrencilerinin Öğrenmede Öz-Düzenlemeyi Öğrenme Becerilerinin İncelenmesi
}

\author{
Meryem ÖZTURAN SAĞIRLI* \\ Esra AZAPAĞASI ${ }^{* *}$
}

\begin{abstract}
ÖZ: Bu araştırmanın amac1; üniversite öğrencilerinin özdüzenleme becerilerini etkin bir şekilde kullanıp kullanmadığını araştırmak ve bu amaç altında öğrencilerin öz-düzenleme becerilerini düzenlemek için ne gibi faaliyetler yürüttüğünü öğrenmektir. Araştırma nitel bir çalışma olup betimsel analiz yapılmıştır. Veri toplama tekniği olarak bireysel ve odak grup görüşmeleri kullanılmış ve veriler NVivo programı ile analiz edilmiştir. Araştırma sonuçları; öğrencilerin öz-düzenleme becerilerinden sıklık sırasına göre öğrenme stratejileri kategorisinde bilişüstü öz-düzenlemeyi, zaman/çalışma çevresinin düzenlenmesini, tekrarlama, ayrıntılandırma, arkadaştan öğrenme, örgütleme ve yardım arama, kritik düşünmeyi ve çaba düzenlemeyi kullandıklarını; Motivasyon kategorisinde ise sınav kaygısı, öğrenme inanışlarının kontrolü, öz yeterlik, amaca odaklanma, hedef yönelimi ve görev değeri gibi kavramların ortaya çıktığını göstermiştir.
\end{abstract}

Anahtar Kelimeler: Öz-düzenlemeyi öğrenme, öğrenme stratejileri, motivasyon.

${ }_{* \star}^{*}$ Research Assist. , Erzincan University, Faculty of Education, msagirli@erzincan.edu.tr Atatürk University, Institute of Science, eses_asra@hotmail.com 


\section{GİRIŞ}

Günümüz öğrenmesine damgasını vurmuş olan aktif öğrenme, öğrencilere kendi farkındalık düzeylerini yükseltme konusunda görevler yüklemiştir. Kendi düşünmelerinin farkında olmaya ek olarak bilişleri hakkında da daha fazla bilgi sahibi olmanın farkındalığını yükseltmek ve böylece en iyisini öğrenme eğiliminde olmak, kendi öğrenmesini kendisi sağlayan öğreniciler (bağımsız öğreniciler-öz-düzenleyici öğreniciler) olabilme yolunu açmıştır. Dahası öz-düzenleyici öğrenici olmaya açılan kapı, öğrenicinin kendi biliş, metabiliş ve öğrenme özelliklerinin farkında olması kadar motivasyon konusunda da farkındalık düzeyinin yükselmesini sağlamıştır.

Öz-düzenleyici öğreniciler; belli bir öğrenme durumunu doğru olarak tanıma, öğrenebilmesi için en uygun öğrenme stratejisini seçme, stratejinin ne derece etkili olduğunu inceleme ve öğrenmeyi gerçekleştirene kadar güdülenmiş olarak yeterli çabayı gösterme işlem basamaklarını etkili olarak uygulayabilen öğrenicilerdir (Arrends, 1979). Derry ve Murphy (1986)'ye göre öz düzenleyici öğreniciler hedefi analiz etme ve tanımlama, stratejiyi planlama, stratejiyi uygulama, stratejinin sonuçlarını izleme ve stratejiyi uygun hale getirme halinde beş basamaklı olan ve aynı zamanda da yukarıdaki dört basamağı içine alan yaklaşımı benimseyen öğrenicilerdir. Dolayısıyla öz-düzenleyici öğreniciler, öz-düzenleme kavramının öneminin bilincinde olup uygulayan öğrenicilerdir.

Öz-düzenlemeyi öğrenme veya öz-düzenleme Bandura'nın sosyal bilişsel kuramına dayalı olup, bu kuramın dayandığ oluşturmaktadır. Bu ilke insanların ne kadar çalışacaklarını, ne kadar uyku uyuyacaklarını, neler yiyeceklerini, neler içeceklerini ne kadar konuşacaklarını, toplumda nasıl davranacaklarını... vb.birçok davranışlarını kendilerinin kontrol etmesi esasına dayanır (Senemoğlu, 2004). Zaten sosyal bilişsel kuramcılara göre öz-düzenlemeyi öğrenme, sadece kişisel süreçler ile tanımlanamaz. Bu süreçlerin çevresel ve davranışsal olaylar tarafından da etkileneceği dikkate alınmalıdır. Bandura (1977)'ya göre de insanların davranışları, sadece dışsal pekiştireçler ve cezalarla kontrol edilemez yani insanlar davranışlarını büyük ölçüde kendi kendilerine düzenlerler.

Sosyal bilişsel kuramcilardan biri olan Zimmerman da öğrenicilerin kendi öğrenme süreçlerinde meta-bilişsel, motivasyonel ve aktif olma derecelerine göre öz-düzenleyici olarak tanımlanabileceklerini söylemiş (Zimmerman, 1986), öğrenicilerin kalifiye bir öz-düzenleyici olabilmeleri için öz-düzenleyici stratejilerinin kullanımına, performans becerilerindeki öz yeterlik algılarına ve kendi akademik amaçları hakkındaki düşüncelerine 
dikkat çekmiştir (Zimmerman, 1989). Yukarıdaki tanımdaki öz-düzenleyici stratejiler öğrenme stratejileri, bilgi ve yetenek elde etmekle direk bağlantılı olan bilgiyi transfer etme, organize etme, yardım arama, tekrarlama gibi metodları; öz yeterlik kişilerin eylemleri uygulamak ve organize etmek için var olan algılarını; akademik amaçlar ise notlar, sosyal statü, mezun olduktan sonraki iş firsatları gibi ortama ve zamana göre çeşitlilik gösterebilecek amaçları içerir. Yine Zimmerman (1998) öz-düzenlemeyi; öngörü, performans kontrolü ve öz-yargılamadan oluşan üç aşama ile kavramsallaştırmıştır. Bu üç aşamadan öngörü aşaması, gerçek performansın önünde gider ve amaçlar ve modelleme gibi olaylar için ortam oluşturan süreçlerle ilgilidir; performans kontrol aşaması, öğrenme stratejilerinin kullanımı, geribildirim ve sosyal karşılaştırma gibi öğrenme boyunca meydana gelen dikkati ve faaliyeti etkileyen süreçleri içerir; performanstan sonra meydana gelen öz-yargılama aşaması boyunca öğreniciler gerekli stratejileri kullanarak, amaç kümelerini değerlendirerek fikirlerinin yeterliği hakkında yargıda bulunurlar. Zimmerman ve Shunk (2007) ise özdüzenlemenin gelişiminin sosyal bilişsel modelini formüle etmişlerdir (Tablo 1). $\mathrm{Bu}$ model gelişimin gözlemsel (observational), benzemeye çalışma (emulative), öz-kontrollü (self-controlled) ve öz-düzenleyici (self-regulated) olmak üzere sosyal kaynaklarla başlayan ve ardından kendi kaynaklarına dönen dört seviyede olduğunu kabul eder. Buradaki ilk iki seviye sosyal faktörlere daha çok bağlıyken, son iki seviye daha çok öğrenici tarafindan etkilenmeye bağlıdır (Zimmerman ve Schunk, 2007).

Tablo 1:Öz-düzenleme Gelişiminin Sosyal Bilişsel Modeli

\begin{tabular}{ll}
\hline Aşama & Temel Özelliği \\
\hline Gözlem & Model öğretimden yeteneğin kazanımı \\
Benzemeye Çalışma & $\begin{array}{l}\text { Sosyal rehberlik ve geribildirimle yeteneğin ortaya } \\
\text { konması }\end{array}$ \\
Öz-Kontrol & $\begin{array}{l}\text { Yeteneğin içselleştirilmesi ve bağımsı biçimde ortaya } \\
\text { konması }\end{array}$ \\
Öz-Düzenleme & $\begin{array}{l}\text { Kişisel ve çevresel şartların değişimine yeteneğin } \\
\text { adaptasyonu }\end{array}$ \\
\hline
\end{tabular}

Eğitimde öz-düzenleme alanına büyük katkılar sağlayan Paul R. Pintrich, bu alanın birçok savunucusunu, kuramcısını, araştırmacısını yetiştirmiş ve eğitime öz-düzenlemeyi uygulayarak eğitimin kapsamını 
genişletmiştir. Schunk (2005), Pintrich'in katkılarını öz-düzenlemeyi öğrenmek için kavramsal bir çerçeve hazırlaması; motivasyonel süreçleri vurgulamas1; öğrenme, motivasyon ve öz-düzenleme üzerindeki araştırmalar; öz-düzenlemeyi öğrenmek için aracılıklar; eğitimsel bağlamdaki öz-düzenlemenin kompleks oluşu ve motive edici stratejiler ölçeği (MSLQ) başlıklarıyla açıklamıştır. Burada Pintrich'in kavramsal çerçevesinde öz-düzenleme modeli; öngörü-tasarlama-eylem, motivasyon süreçleri, kontrol ve tepki-yansıtma olmak üzere öz-düzenlemenin dört aşamasını içerir ve her bir aşama için dört muhtemel öz-düzenleme bölgesi vardır (Tablo 2). Bu aşamalar ve görevleri Zimmerman (2005) tarafindan şu şekilde açıklanmıştır.

Tablo 2 Öz-Düzenlemeyi Çalışma için Kavramsal Çerçeve

\begin{tabular}{lll}
\hline Öz-Düzenleme Aşamaları & Öz-Düzenleme Bölgeleri \\
\hline $\begin{array}{l}\text { Öngörü-Planlama-Eylem } \\
\text { (Forethought, Planning, Activation) }\end{array}$ & Biliş & (Cognition) \\
İzleme (Monitoring) & \multicolumn{2}{c}{ Motivasyon (Motivation) } \\
$\begin{array}{l}\text { Kontrol (Control) } \\
\text { Tepki-Yansitma (Reaction-Reflection) }\end{array}$ & $\begin{array}{l}\text { Davranış (Behavior) } \\
\text { Bağlam }\end{array}$ & (Context) \\
\hline
\end{tabular}

Birinci aşamada öz-düzenleme olabilecek bilişsel süreçler; amaçları, ön konu bilgisini ve metabilişsel bilgiyi, motivasyonel süreçler; amaca odaklanma, öz-yeterlik, görev değeri ve ilgileri, davranışsal süreçler; zamançaba planlanması ve davranışın ön gözleminin planlanması, bağlamsal süreçler ise öğrencilerin görev ve bağlam hakkındaki algılayışlarını içerir. İkinci aşama boyunca bilişsel izleme; öğrenmenin dinamik metabilişsel yargılarına (bir kişinin neyi bildiği ve neyi anlamadığı hakkındaki inançlarını), ve metabilişsel farkındalığına, motivasyonel izleme; kişinin öz güveninin, değerlerinin, sonuçların algılanan sebeplerinin farkında olmasına, davranışsal denetim; zaman, çaba yönetimi ve etkilerinin değerlendirilmesine, bağlamsal denetim ise görev şartlarının değişken olup olmadığına karar verme denetimine karşılık gelir. Üçüncü aşama boyunca bilişsel kontrol; öğrenenlerin bilişlerini adapte etmek ve değiştirmek için kullandıkları bilişsel ve metabilişsel aktiviteleri, motivasyonel kontrol; düzenleme işlemleri, kendi içinde olumlu konuşma yoluyla öz yeterliğin sağlanmasını, davranışsal kontrol; 1srarcılığı, çaba harcamayı, gerektiğinde yardım almayı, bağlamsal kontrol ise konuyu daha da anlaşılır yapma yöntemlerini kapsar. Dördüncü aşamada öğrenenler performanslarını değerlendirirler ve bu değerlendirmeler motivasyon davranışsal ve bağlam düzenlemek için sarf edilen çabalara temel oluşturur. Motivasyonel tepkiler 
öğrenenlerin motivasyonlarının azaldığını düşündüklerinde motivasyonlarını arttırıcı uygulamaları; davranışsal tepki ve yargılar kişinin zamanını etkili bir şekilde kullanıp kullanmadığı gibi kişinin davranışlarının yorumunu; bağlamsal tepki ve yansımalar ise görev istekleri ve kavramsal faktörlerin değerlendirilmesine karşılık gelir.

Son yirmi yılda öz-düzenleme ile ilgili yapılan araştırma sayısı artmış, bu araştırmaların çoğu ögrenme stratejileri ve motivasyonel inançlar ile ders başarısı arasında pozitif yönde anlamlı bir ilişki olduğunu ortaya koymuştur. Pintrich ve De Groot (1990) öz-düzenlemeyi öğrenme ve motivasyon ile sınıf akademik performansı arasındaki ilişkiyi araştırmışlar ve yüksek seviyede öz yeterlik ve görev değerinin yüksek seviyede bilişsel strateji kullanımıyla; yüksek seviyedeki öz yeterlik ve yüksek seviyede görev değerinin daha yüksek seviyede öz-düzenlemeyle ilgili olduğunu bulmuşlardır. Eom and Reiser (2000) ise öz-düzenlemeyi öğrenme stratejilerinin kullanımının başarı ve motivasyon üzerindeki etkisini incelemiş; daha yüksek düzeyde öz-düzenleme yeteneklerini kullananların daha düşük düzeyde öz-düzenleme yeteneklerini kullananlara göre bilgisayar tabanlı dersleri daha iyi öğrendikleri sonucuna varmışlardır. Üredi ve Üredi (2005) yaptıkları çalışmanın sonucunda öz-düzenleme stratejileri ve motivasyonel inançların matematik başarısına ilişkin toplam varyansın \%30'unu açıkladığını bulmuşlardır. Öz-düzenlemeyi öğrenme konusunda ülkemizde ve dünyada birçok araştırma yapılmasına rağmen bu araştırmaların çoğu nicel araştırma yöntemiyle sınırlı kalmıştır. Bu araştırma öz-düzenlemeyi öğrenme konusunda nitel araştırma boyutunda alan yazında var olan boşluğu doldurmayı amaçlamıştır. Bu sayede de öz-düzenlemeyi öğrenmeyi oluşturan boyut ve alt boyutlara daha derinlemesine anlam kazandırılmaya çalışılmıştır.

\section{Araștırmanın Amacı}

$\mathrm{Bu}$ araştırmanın amac1; üniversite öğrencilerinin öz-düzenleme becerilerini etkin bir şekilde kullanıp kullanmadığını incelemek ve bu amaç doğrultusunda öğrencilerin öz-düzenleme becerilerini düzenlemek için ne gibi stratejiler yürüttüğünü ortaya çıkarmaktır. Alanyazında öz-düzenleme konusuna birçok tanım getirilmekte ve giriş kısmında da açıklandığı gibi öz -düzenleme konusunun kavramsal çerçevesi farklı başlıklarla ele alınmaktadır. Bu makalede öz-düzenleme konusunun sınırları Pintrich ve De Groot'un (1990) Öğrenmede Motive Edici Stratejiler Ölçeğindeki (MSLQ) başlıklar ve alt başlıklarıyla çalışılmıştır. 


\section{YÖNTEM}

$\mathrm{Bu}$ çalışma nitel araştırma yaklaşımı doğrultusunda yürütülmüş, betimsel analiz yapılmıştır. $\mathrm{Bu}$ yaklaşıma göre elde edilen veriler daha önceden belirlenen temalara göre özetlenir, yorumlanır ve bu tür analizlerde amaç elde edilen bulguları düzenlenmiş ve yorumlanmış bir biçimde okuyucuya sunmaktır (Yıldırım ve Şimşek, 2006). Nitel araştırma yaklaşımının bireylerin kendi eylemleri ile ilgili bakış açılarını anlama güdüsü; davranışın içinde oluştuğu bağlamı ve doğal ortamı dikkate alan temeli ve araştırılan konu ile ilgili olarak olabildiğince ayrıntılı ve betimleyici bir anlatının ortaya konulabilmesine ilişkin vurgusu (Bogdan ve Biklen, 1992) bu çalışmada dikkate alınmış ve gerekleri yerine getirilmeye çalışılmıştır.

\section{Araştırma Grubu}

$\mathrm{Bu}$ araştırmada; veri toplama teknikleri ile elde edilen verilerin ayrıntılı ve derinlemesine olması, araştırma sonucunda ulaşılan sonuçların geçerliğine ve güvenirliğine ilişkin önemli göstergesi (Şimşek ve Yıldırım, 2000) olması açısından araştırma grubu ayrıntılarıyla açıklanmıştır. Araştırmada, Atatürk Üniversitesi Kazım Karabekir Fakültesi İlköğretim Bölümü Matematik Öğretmenliği ve Erzincan Üniversitesi Eğitim Fakültesi İlköğretim Bölümü Matematik Öğretmenliği olmak üzere iki farklı üniversiteden öğrenciler araştırmaya katılmıştır. Atatürk Üniversitesinden her sınıf kademesinde öğrenim gören birer öğrenci olmak üzere toplam dört kişi alınmıştır. Erzincan Üniversitesinden ise 1.sınıfta öğrenim görmekte olan iki kişi, 2.sınıfta öğrenim görmekte olan dört kişi, 3.sınıfta öğrenim görmekte olan beş kişi, 4.sınıfta öğrenim görmekte olan dört kişi olmak üzere toplam on beş kişi alınmıştır. Sonuç olarak araştırma grubuna Atatürk Üniversitesinden iki bayan iki erkek, Erzincan Üniversitesinden ise sekiz bayan yedi erkek öğrenci olmak üzere toplam on bayan dokuz erkek öğrenci katılmıştır.

Araştırmaya katılan öğrencilerin sınıf akademik ortalamalarının düşük, orta, yüksek şeklinde üç farklı seviyeden alınmasına dikkat edilmiştir. Çünkü akademik başarının öz düzenlemeyle ilişkisi dikkate alınmıştır (Üredi ve Üredi, 2005). Hem bireysel hem de odak grup görüşmeleri yapılırken her üç seviyedeki akademik başarıya sahip olan öğrencinin ve her sınıf seviyesindeki öğrencinin katılımı dikkate alınmıştır. 


\section{Verilerin Toplanması}

$\mathrm{Bu}$ araştırmada veri toplama tekniği olarak bireysel görüşme ve odak grup görüşmesi kullanılmıştır. Atatürk ve Erzincan Üniversitesinden her sınıf kademesinde öğrenim gören birer öğrenci ile bireysel görüşme yapılmış ayrıca Erzincan Üniversitesinden iki ayrı grupla odak grup görüşmesi yapılmıştır. Bu odak grup görüşmelerinden birincisinde, 2.sınıfta öğrenim görmekte olan iki kişi, 3.sınıfta öğrenim görmekte olan iki kişi, 4.sınıfta öğrenim görmekte olan iki kişi olmak üzere toplam altı kişi ile görüşülmüştür. İkinci odak grup görüşmesinde ise 1.sinıfta öğrenim görmekte olan bir kişi, 2.sınıfta öğrenim görmekte olan iki kişi, 3.sınıfta öğrenim görmekte olan iki kişi, 4.sınıfta öğrenim görmekte olan bir kişi olmak üzere toplam altı kişi ile görüşülmüştür. Bireysel görüşmelerin süresi 10 ile 25 dakika arasında değişirken, odak grup görüşmelerin süresi 30 ile 60 dakika arasında değişmiştir. Görüşmeler, görüşülen kişilerin izni alındıktan sonra ses kayıt cihazı ile kaydedilmiştir.

Hem bireysel hem de odak grup görüşmelerinde yarı yapılandırılmış görüşme formu kullanılmıştır. Bu formun taslağı Motive Edici Stratejiler Ölçeğindeki (MSLQ) başlıklar ve alt başlıkların cevabını sorgulayacak şekilde hazırlanmıştır. Taslak formun uygulanması, daha sonra çalışma grubundan çıkarılmış olan dört öğrenci ile bireysel görüşme şeklinde yapılmıştır. Bu uygulamanın değerlendirilmesi sonucu, taslak görüşme formundan bir soru çıkarılıp onun yerine bir soru eklenmiş, bir başka soruda da değişiklik yapılmıştır ve böylece geliştirilmiş görüşme formu elde edilmiştir. Geliştirilmiş görüşme formunun son hali sırasıyla şu soruları içermektedir: Düzenli olarak ders çalışmak hakkında ne düşünüyorsunuz? Matematik dersine nasıl çalışıyorsunuz? Matematik dersine çalışıyorken hangi öğrenme stratejilerini kullanıyorsunuz? Sınavlardan önce ve sonra neler hissediyorsunuz? Matematik sınavlarında başarısız olduğunuzda (olursanız), niçin başarısız olduğunuzun nedenlerini sorgular mısınız? Ders çalışma alışkanlıklarınıza üniversitenin etkilerinden (olumlu-olumsuz) bahsedebilir misiniz?

MSLQ üniversite öğrencilerinin motivasyonel uyumlarının ve üniversitedeki dersleri için farklı öğrenme stratejileri kullanımlarını değerlendirmek için geliştirilen bir öz-değerlendirme aracıdır (Garcia ve Pintrich, 1995). 1980'lerin başlarında Bill McKeachie ve Paul Pintrich öğrencilerin motivasyonunu ve öğrenme stratejilerinin kullanımını değerlendirmek için bir araç geliştirmeye başlamışlardır ve MSLQ' nun bu ilk versiyonu liselerde öğrenme için öğrenmenin etkililiğini değerlendirmek için kullanmıştır; MSLQ geliştirilmeye başlandıktan yaklaşık on y1l sonra daha da az son şekline ulaşmıştır (Anthony ve Artino, 2005). MSLQ, 81 
maddeden oluşmakta ve ölçek maddeleri motivasyon bölümü ve öğrenme stratejileri bölümü olmak üzere iki ana kategoriye ayrılmaktadır. Motivasyon bölümü; hedef yönelimi, amaca odaklanma, görev değeri, öğrenme inanışlarının kontrolü, öz yeterlik, sınav kaygısı, çaba düzenleme, yardım arama, arkadaştan öğrenme alt başlıklarından oluşurken; öğrenme stratejileri bölümü de tekrarlama, ayrıntılandırma, organize etme, kritik düşünme, metabilişsel öz-düzenleme, zaman-çalışma çevresinin düzenlenmesi alt başlıklarından oluşmaktadır. Bu çalışmada da alt başlıklar olan hedef yönelimi, amaca odaklanma, görev değeri, öğrenme inanışlarının kontrolü, öz yeterlik, sınav kaygısı, çaba düzenleme, yardım arama, arkadaştan öğrenme, tekrarlama, ayrıntılandırma, örgütleme, kritik düşünme, bilişüstü öz-düzenleme, zaman-çalışma çevresinin düzenlenmesi kodlara karşıllk gelirken; başlıklar olan motivasyon ve öğrenme stratejileri kategorilere karşılık gelmektedir. Temamız ise öz-düzenlemeyi öğrenmedir.

\section{Verilerin Analizi}

$\mathrm{Bu}$ araştırmada veri toplama tekniği olarak bireysel görüşmeler ve odak grup görüşmeleri kullanılmıştır. Yapılan bireysel görüşmeler ve odak grup görüşmeleri, yazılı hale getirildikten sonra elde edilen verilerin metinleri birçok defa okunmuş ve önceden belirlenmiş olan kod, kategori ve temalar NVivo programının yardımı ile oluşturulmuş ve yine bu program sayesinde verilerin analizi yapılmıştır. Sonuçlar raporlaştırılırken alıntılar yapılmıştır. Alıntılarda verilen isimler gerçek kişilerin isimleri olmayıp takma isimlerdir.

\section{BULGULAR}

Daha öncede açılandığ1 gibi öz-düzenlemeyi öğrenme veya özdüzenleme kişilerin kendi amaçlarını başarma ve öğrenme süreçlerinde metabilişsel, motivasyonel ve davranışsal olarak aktif olmaları ile tanımlanır. MSLQ'da öz-düzenleme, motivasyon ve öğrenme stratejileri olarak ikiye ayrılmıştır. Aşağıda bu başlıklar alt başlıklarıyla beraber bireysel ve odak grup görüşmelerinden alınan verilerle değerlendirilmiştir. Bulgular her bir alt başlıkta ayrı ayrı sunulmuştur.

\section{Öğrenme Stratejileri}

Öğrenme stratejileri bölümü, öğrencinin bilişsel ve metabilişsel stratejileri kullanımı ve farklı öğrenme kaynaklarını yönetimi ile ilgilidir. Öğrenme stratejileri bölümünü oluşturan boyutlar aşağıda Şema 1'de gösterilmiştir. 
Şema 1 Öğrenme Stratejileri Modeli

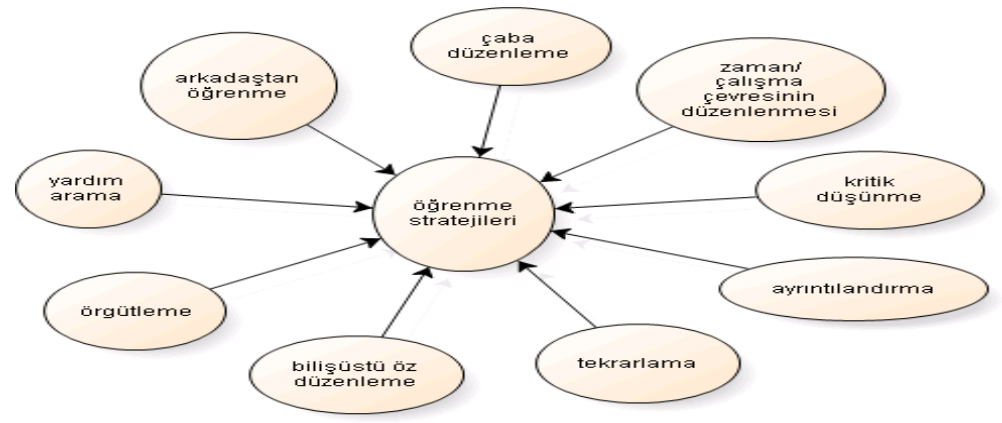

Öğrenme stratejilerini oluşturan boyutlarla ilgili öğrencilerin vermiş oldukları görüşlerin sayısı ise Tablo 3'te gösterilmiştir.

Tablo 3 Cinsiyet ve Sınıf Değişkenine Göre Öğrenme Stratejilerini Oluşturan Boyutlara İlişkin Frekans Tablosu

\begin{tabular}{lllllll}
\hline Alt Boyutlar & Erkek & Kız & 1.Sinıf & 2.Sınıf & 3.Sinıf & 4.Sinıf \\
\hline Tekrarlama & 8 & 9 & 2 & 5 & 5 & 5 \\
Ayrıntılandırma & 7 & 9 & 3 & 5 & 3 & 5 \\
Örgütleme & 6 & 4 & 2 & 3 & 3 & 2 \\
Bilişüstü Öz-Düz. & 8 & 10 & 3 & 5 & 5 & 5 \\
Yardım Arama & 4 & 6 & 3 & 2 & 0 & 5 \\
Arkadaştan Öğrenme & 8 & 6 & 3 & 4 & 4 & 3 \\
Zaman/Çalışma Çev. Düz. & 9 & 9 & 2 & 5 & 5 & 6 \\
Çaba Düzenleme & 3 & 3 & 1 & 2 & 1 & 2 \\
Kritik Düşünme & 4 & 4 & 1 & 2 & 0 & 5 \\
\hline
\end{tabular}

Tablo 3 incelendiğinde öğrenme stratejilerini oluşturan alt boyutlarda en çok görüş belirtilen kavramın zaman ve çalışma çevresini düzenleme ve bilişüstü öz-düzenleme boyutları, en az görüş belirtilen kavramın ise çaba düzenleme boyutu olduğu söylenebilir. Ayrıca yine Tablo 3'e göre kızların ve erkeklerin belirttiği görüş sayısı hemen hemen eşittir.

Tekrarlama: Tekrarlama kodu ile kastedilen öğrencilerin öğrenmeye çalıştıkları konuyu sürekli sesli olarak tekrar etmeleri, ders notlarını ve kitapları tekrar tekrar okumaları, önemli kavramları hatırlamak için önemli sözcükleri ezberlemeleri ya da önemli bilgileri listeleyip ezberlemeleridir (Pintrich ve De Groot, ). Öğrencilerin çoğu, tekrarı düzenli ders çalışmanın ön şartı olarak görmüşler ve ellerinden geldiği kadar düzenli ders çalışmaya gayret ettiklerini söylemişlerdir.3.sınıf ögrencilerinden Harun bu durumu şöyle ifade etmiştir:

...Düzenli ders çalışmak şu açıdan önemlidir. Hem konular birikmez, hem de derste işlediğimiz konular tekrar işlemiş oluruz. 
Tekrarlama çoğu öğrenciye göre de not alma ile gerçekleşir. Yine 3.sınıf öğrencilerinden İpek;

...Buna düzenli çalışmak denilir mi bilmiyorum ama derslerde not alırım. Not alyyorken de defterime yazmam müsveddeye yazarım ve yurda gittiğimde onu defterime daha düzenli bir şekilde yazarım. Tekrar da oluyor.

şeklinde görüşünü belirtmiş, 3.sınıf öğrencilerinden Nurgül ise fikrini şöyle belirtmiştir.

...Iıtm nasıl not allyorum; mesela bir konuyu çalışıyorum, daha sonra onu boş bir kâğıda yazmaya çalışıyorum. Ĕger hani bir teoremse çalıştığım bir konu, yazarak çalışmayı daha çok seviyorum okuyarak çalışmaktansa...

Bazı öğrenciler ise not almayı tamamen reddettiklerini ifade etmiştir.2.sınıf öğrencilerinden Murat;

...Ben yazarak çalışma derken ben yazarak hiç çalışamam çünkü aslında yazmak zor geliyor bana. Hatta tanımlar bile ezberlemem gerekirken oda da arkadaşlarım yazar onlar yatar 12 den sonra ben onlardan tanımları yazılmış halini alır sonra gelir onları ezberlerim.

şeklinde görüş belirtmiş;4.sınıf öğrencilerinden Ufuk ise aşağıdaki notu ifade etmiştir.

...Not tutmuyorum da, arkadaşlarımdan aldiğım notları okuyorum.

Öğrencilerin belirttiği görüşlere göre, genelde derslerden sonra tekrar yapıldığ 1 gözlenmiş ve tekrar için çalıșma çevresinin illa da yurt, ev ya da belirlenmiş bir çalışma mekânı olmasına gerek olmadığı görülmüştür.4.sınıf öğrencilerinden Tolga da bu duruma aşağıdaki örneği vermiştir.

...Çalışırken bir kayda alıyorum. Onları daha sonra mesela yolda yürürken otobüste bunlarl dinliyorum.

Tekrarlamayı öğrencilerin ezber yaparken de oldukça kullandıkları görülmüştür. Ezberi genelde tanımları ezberlemek için kullandıklarını söyleyen öğrenciler, ezberi çok da onaylamadıklarını belirterek, tanımları genelde anlamaya çalıştıklarını fakat cümlelerini birbirine bağlamak ve sınavlarda kâğıda aktarabilmek için bazı yerleri ezberlemeye mecbur kaldıklarını ifade etmişlerdir. Yine tanımları öğrenmek için öğrencilerin bir kısmının tanımları yazdığı bir kısmının ise yazılanları okuyarak öğrenmeye çalıştıkları yapılan görüşmelerden anlaşılmıştır.

Ayrıntılandırma: Ayrıntılandırma kodu; kitaplardan okunanları, derste anlatılanları ve ders çalışmaları gibi farklı kaynakları bir araya getirerek bilgi toplamayı, bir konunun içindeki fikirleri mümkün olduğunca diğer derslerle 
ilişkilendirmeye çalışmayı, dersle ilgili kitap, dergi... vb. okunurken, okunanları hali hazırda bilinenlerle ilişkilendirmeye çalışmayı, okumalardaki ve ders notlarındaki ana fikirlerin kısa özetlerini yazmayı, derste öğretmen tarafından anlatılan kavramlarla, okunarak öğrenilenler arasında ilişki kurarak konuyu anlamayı çalışmayı ve dersle ilgili kitaptan edinilen bilgileri, ders anlatımlarında ya da tartışmalarda kullanmayı içerir (Pintrich ve De Groot, 1990). Ayrıntılandırma kodunun içeriğinden de anlaşılacağı gibi bu kod daha çok eski bilgilerle yeni bilgiler arasında ilişki kurma üzerine yoğunlaşır. Öğrencilerin hemen hemen hepsi ayrıntılandırma konusunda görüş belirtmiş olup bir kısmı yeni derse, eski dersi tekrar ederek çalışmaya başladığını söylemiştir. Bu görüşe sahip olan 3.sınıf öğrencilerinden Nurgül görüşünü şu şekilde ifade etmiştir:

...Eeee mesela istatistik dersini örnek verecek olursam; ilk dönem işte gördügümü̈ fonksiyonlar marjinal falan onlar bilmesek mesela şu anda ki istatistikte biraz karmaşa yaşarız. En azından o defterimde yanımda olduğu için onları da sik sik tekrar yapıyorum sinavlara hazırlanırken hani marjinaller böyleymis yani hocanın yazdırdı̆̆ formülden değil de nerden çıktı̆̆ını biliyorum.

Matematik dersinin yı ğılmalı bir ders olmasının ayrıntılandırmayı kullanmayı gerektirdiği 1.sınıf öğrencisi olan Nihal tarafından şu şekilde ifade edilmiştir;

...Söyle matematik zaten bir zincir hani bence. Hani bir konuyu anlamadan diğer konuya geçmeniz çok zor. Hani bir bağıntıyı anlamadan fonksiyonu çözememeniz gibi.

Öğrencilerin bir kısmı da yeni konunun öğrenimi için problem-soruörnek çözümü tercih ettiklerinden bahsetmiştir. Bu çalışmada örnek çözümünün ayrıntılandırma kodu içerisinde yer almasının sebebi, yeni bilginin uzun süreli bellekten çağrılıp getirilerek yeni uygulamaya aktarılmaya çalışılmasında hangi bilginin nerede kullanılacağı konusunda ilişkilendirilmenin kullanılmasıdır. Nitekim 4.sınıf öğrencilerinden Tolga:

...Yine özetini muhakkak yazarak çıkartıyorum, bunlarla ilgili örnekler oluyor. Sonunda da genel örnekler çeşitli kitaplardan yabancı kaynaklardan soruları topluyorum. Temiz bir şekilde çözüyorum. Ve not olarak da bunları sakllyorum. Bu şekilde çalışıyorum.

ifadesi ile soru çözümünü nasıl kullandığını aktarmıştır. Bazı öğrenciler için ayrıntılandırmanın öğrenmek için tek gerek şart olduğu da dikkati çeken noktalar arasında olmuştur.3sınıf öğrencilerinden Harun bu konudaki görüşünü aşağıdaki gibi ifade etmiştir.

...bağlantı kurmam, bunları yapmam lazım. Öğrenmem lazım, mantığını kavramam lazım. Arkadaşımızın dediği gibi teoremlerde falan da düz ezber yapamıyorum anlamlandırmam lazım bir şekilde. Öyle çalışıyorum. 
Öğrencilerin bilgilerini ilişkilendirmek adına farklı kaynaklar arama yolunu da tercih ettikleri gözlenmiştir. Bunu yaparken bir grup öğrenci bol soru bulma amacı taşırken bir grup öğrenci de farklı kaynaklardan bilgi toplama amacı taşımaktadır. Öğrenciler burada kaynak olarak daha çok, farklı ders kitaplarını ve interneti kullandıklarını belirtmişlerdir.

$\mathrm{Bu}$ görüşlerin yanında derslerde ayrıntılandırma stratejisini kullanamadıklarını söyleyen ögrenciler de olmuştur. 4.sınıf öğrencilerinden Hülya;

... Matematikte değil ama başka derslerde yapıyorum Lise dersleri hariç üniversitede gördüğ̈̈müz bu derslerle de iki ders arasında fazla bir bağlantı kuramadık. Yani lineer cebir ile bir analiz arasında hiçbir bağlantı yok.

ifadesi ile bu görüşü paylaştığını belirtmiştir. Ayrıntılandırmanın önemine anlayan ve bunun sadece konular arasında değil aynı zamanda günlük hayatla da yapılmasını öneren 2.sınıf öğrencilerinden Kenan ve 3.sınıf öğrencilerinden Hatice görüşünü şöyle ifade etmiştir;

...ezber dersi değil belirli kuralları var, neyin nerden geldiği belli. Bilim adamları kafalarından atmamışlar bunu yani. O kurallara bile anlamlılık katmak gerekiyor. Hocam yani günlük yaşamla ilişkilendirebiliriz her şeyi ilişkilendiremiyoruz ama bazı şeyleri ilişkilendirmek kesinlikle gerekiyor.

...Herkes sinavlara çalışlyor fakat on gün sonra gidin o konuyla ilgili bir şey sorun hiçbir şey yok, hatırlanmıyor. Matematik yı̆̆llmalı bir ders. En güzel yöntem bence somutlaştırmak, anlam vermek. Ezber belki başlangıçta olabilir ama geri kalanlar da onların üzerine inşa edilerek gidecek.

Örgütleme: Örgütleme kodu; derse çalışırken düşüncelerin organize edilmesine yardım etmesi için konuların ana başlıklarını çıkarmayı, kitapları ve ders notlarını gözden geçirip en önemli yerleri bulmaya çalışmayı, ders konularını organize etmeye yardım etmek için basit grafikler, tablolar, diyagramlar yapmayı ve ders için çalışırken ders notlarının üzerinden gitmeyi, önemli kavramların listesini çıkarmayı içerir (Pintrich ve De Groot, 1990). Örgütleme stratejileri öğrencilerin öğrendikleri konudaki temel fikir ve yan fikirleri görmesini sağlayarak yeni öğrenilen konunun anlamlandırma düzeyini yükseltir.

Öğrenciler örgütleme stratejilerinde on görüş belirtmişlerdir. Not alma stratejisinin örgütleme ile olan kısmı; bilgiyi yeniden organize ederek ayrı bir yere not alma, kendi için daha anlamlı olacak şekilde organize etme şeklinde gerçekleşebilir.3.sınıf öğrencilerinden Burcu bu durumu; 
... Bir de önemli noktalarl yazarım kaydederim. Defterimdedir ama başka bir kâğılda da not tutarım yazarım çok önemli yerleri

.ifadesi ile, 2.sınıf öğrencilerinden Mustafa ise;

... Aynı şekilde değil de önemli gördüğüm kısımların özetini çıkartıp dosyamda sakllyorum, sınavlara hazırlanırken de başvurmak için. Yani tüm derslerin özetleri elimde mevcut.

ifadesi ile belirtmiştir. Diğer bir örgütleme stratejisi olarak da öğrencilerin altını çizme tekniğinden bahsettikleri ve bu tekniğinde önemli tanımların altını çizme, cümlenin en önemli yerini çizme şeklinde meydana geldiği yapılan görüşmelerden anlaşılmıştır. Ayrıca 4.sınıf öğrencilerinden Tolga örgütleme stratejisini;

...Örgütleme şu şekilde; yani zaten kitapların içindekiler kısmına baktığınız zaman belli bir düzen içerisinde veriliyor. Genelde ben de o düzeni takip ediyorum.

ifadesi ile pusula olarak kullandığını belirtmiştir.

Bilişüstü Öz-Düzenleme: Bilişüstü öz-düzenleme öğrencinin kendi bilişsel ve duyuşsal özelliklerini tanıyarak kendine özgü bir çalışma stratejisi geliştirmesi, kendi öğrenmelerini izlemesi ve öğrenme sonuçlarına göre var olan stratejiyi sürdürmesi ya da yeni bir strateji kullanmaya karar vermesi ile ilgilidir. Bu kod; derse çalışırken odaklanmaya yardım edecek sorular oluşturmay1, kitap, dergi, basılı materyalden çalışırken bir yer anlaşılmadığ 1 zaman geri dönüp anlamaya çalışmayı, ders ile ilgili verilenlerin anlaşılmadığı takdirde geri dönüp çalışmayı, dersin gereklerine ve öğretmenin ders işleyiş stiline uymak için çalışma şeklini değiştirmeye çalışmayı, derse çalışırken sadece okumak yerine konu üzerinde düşünmeye ve ondan ne öğrenilmesi gerektiğine karar vermeyi, ders için çalışırken her bir etkinliği yönlendirmek için kendine hedefler koymayı, hangi kavramları iyi anlamadığını belirlemeye çalışmayı, yeni ders konularını çalışmadan önce nasıl organize edildiğini görmek için sık sık gözden geçirmeyi, çalışılan materyali anladığından emin olmak için kendine sorular sormayı içerir (Pintrich ve De Groot, 1990).

Bilişüstü öz-düzenleme stratejisinin öğrenciler tarafindan en çok kullanım şeklinin, dersin öğretmenine göre ders çalışma stillerinin oluşturulması olduğu görülmüştür.2.sınıf öğrencilerinden Murat;

...Bir de hocaların sınavina bazı hocalar işlem kabiliyetine önem verir, bazıları deftere arkadaşımızın dediği gibi o şekilde çalışırım.

şeklinde görüşünü belirtmiş, 3.sınıf öğrencilerinden Emel ise; 

ögrrendim.

...Hem hocaların stillerini öğrendim, nasıl çalışmam gerektiğini

şeklinde ifade etmiştir. Ayrıca öğrencilerin öğrenme alışkanlıklarının farkındalık düzeylerinin de çok yüksek olduğuna dikkat edilmiştir. 3.sınıf öğrencilerinden Harun;

...Çalışmak dediğim de şu şekilde işitsel hafizamın pekiyi olmadiğını düşünüyorum. Derste dinlesem bile unutuyorum ama kendim çalışarak gayet iyi öğreniyorum dersleri. Küçüklükten beri böyle bir teknik gelişstirdim kendimce. Kendim çalışarak ögreniyorum.

4.sınıf öğrencilerinden Ufuk;

...Benim adıma düzenli ders çalışmak dağınık ders çalışmaktır. Ben ders çalışırken TV izlerim, müzik dinlerim. Şey derler; genel uyarılmış haliniz düşer, iyi anlayamazsını ama ben kendimi öyle daha iyi hissediyorum.

3.sinıf öğrencilerinden Nurgül;

...Matematik dersine genelde problem çözerek çalışıyorum. Yani tekrar yapmak ezberlemek yerine genelde problem çözüyorum ben. Konuyu daha iyi anlamamı, fikir yürütmemi sağllyor yani o soruyla ilgili ya da ona benzer sorularla ilgili fikir yürütmemi sağllyor. Işslem yeteneğimi geliştiriyor diyeyim.

şeklinde görüşünü belirtmiştir.1.sınıf öğrencilerinden Mehmet ise düzenini bulana kadar yaşadığı kargaşayı şu şekilde açıklamıştır.

...Ben de bu abla ve ăgabeylerimizin dediği gibi başta not tuttum. Yani müsveddeye yazdım, sonra temize geçireyim dedim olmadı çok birikti ve öyle kaldı sonra kâğtları kaybettim. İște önceden günlük çalışayım dedim çalışamadım 1.sınıfım ben de acemilik de vardı. Bir de nasıl çalışacă̆ım nasıl yapacağım bilmiyordum. Bir de hocaya göre çalışmak gerekiyor, mesela bazı hocalar ezber ağırlıklı soruyor. Genelde işte hocaya göre çalışıyorum yani ilk dönem mesela eğitim hocamız biraz daha sıkıydı böyle ezber bakımindan eğitime çok önem veriyordu matematiği daha çok düzgün yazıyla alakalıydı. O da yazım güzel değildi öyle geçti bu dönemde hocaları tanıyıp işte hocalara göre çalışacağım artık.

Yine 3.sinıf öğrencilerinden İpek;

...Ben matematiği okuyarak kesinlikle anlayamam, kesinlikle matematik çalışırken yazmam lazım.

ifadesiyle kendi stratejisinde ne kadar kararlı olduğunu ifade etmiştir. 
Yardım Arama: Yardım arama stratejisi adından anlaşılacağı üzere ders çalışıken daha çok birilerinden ya da farklı kaynaklardan yardım almayla ilgilidir. Öğrenciler yardım alacakları kişi ya da kaynaklara kendi deneyimleri, alışkanlıkları ya da birilerinin tavsiyesi üzerine karar verirler. $\mathrm{Bu}$ kod; öğrencilerin dersteki konuları öğrenmede zorluk çekse bile ödevleri kimseden yardım almadan kendilerinin yapmasını, dersin öğreticisinden anlamadığ kavramları açıklamasını istemesini, derste herhangi bir konuyu anlamadığı takdirde sınıftaki başka bir öğrenciden yardım istemesini, sınıfta gerektiğinde yardım alabileceği arkadaşları saptamaya çalışmasını içerir ( Pintrich ve De Groot, 1990).

Öğrenciler yardım arama konusunda en çok arkadaştan öğrenme şeklini kullanmakta olduklarını ifade etmişlerdir; fakat bu çalışmada arkadaştan öğrenme ayrı bir kod olarak alındığından gerekli görülen ifadeler o kod kapsamında anlatılacaktır. Arkadaştan öğrenme dışında öğrenciler dersin öğretim elemanından, kütüphaneden, internetten yardım aldıklarından bahsetmiş̧lerdir. Yardım aramaya ihtiyaç duyulması konusunda matematik dersinin ilk bakışta anlaşılmasının kolay olmaması konusunun etkili olduğu görülmüştür.3.sinıf öğrencilerinden İpek bu görüşünü;

...Dersi derste dinlemek lazım, hele matematik dersini hocadan dinlemeden hiç anlamam. Kolay bir konu olsa da belki bu ben de bir ön yargı ama hocadan dinlemem lazım matematiği anlamak için.

şeklinde, 4.sınıf öğrencilerinden Hülya;

...Ders sırasında hocayl dinlerim benim öyle bir özelliğim var. Hoca anlattığı zaman anlayamiyorsam sonra bir daha anlayamiyorum. Ebob ekok' u hala anlayamamıs durumdayım yani. O kadar berbat yani hoca anlattyor anliyorum.

ile 4.sınıf öğrencilerinden Hatice ise,

...matematik dersi tek başına çalışılarak ögrenilebilecek bir ders eğil bence. Bunun için mutlaka bir kılavuzun olması gerekiyor. O yüzden hocalarımdan bu konuda iyi istifade etmeye çalışıyorum.

şeklinde belirtmiştir. Bazı öğrenciler internet kullanımını aktif bir şekilde gerçekleştirdiklerini ifade etmişlerdir. 3.sınıf öğrencilerinden Harun' un da iyi bir internet kullanıcısı olduğu aşağıdaki ifadesinden anlaşılmıştır.

...Ben ders çalışırken interneti kesinlikle kullanırım. Mesela sinavdan önce hocamızın anlattığı konuyla ilgili bilgileri internetten indirir göz gezdiririm.

Bazı öğrenciler ise teknolojiden çok fazla anlamadıklarını bu yüzden internet kullanımına yönelmediklerini söylemiş̧lerdir. Öğrenciler kütüphane kullanım amaçlarını konuyu başka kaynaklardan bulma yerine bol örnek bulma ile açıklamışlardır 3.sınıf öğrencilerinden Nurgül amacını şu şekilde;

...kütüphaneye sadece o konuyla ilgili soru bulmak için giderim.

ifade etmiştir. 
Arkadaştan Öğrenme: Arkadaştan öğrenme öğrenciler arasında etkin bir şekilde kullanılan stratejiler arasındadır. Bu kodun etkin bir şekilde kullanılmasının sebebi; öğrencilerin çoğunluğunun üniversitede öğrenim gördükleri süre boyunca yurt, ev gibi ortamlarda arkadaşlarıyla beraber kalmasının getirdiği zorunluluk da olabilir. $\mathrm{Bu}$ zorunluluk öğrencilerin hissettikleri her anda arkadaştan öğrenmesi kolaylığını da beraberinde getirmektedir. Arkadaştan öğrenme; derse çalışırken öğrenilenleri sık sık sınıftan birine ya da bir arkadaşına açıklamaya çalışmayı, dersle ilgili ödevleri tamamlamak için sınıftaki diğer öğrencilerle birlikte çalışmaya gayret etmeyi, derse çalışırken öğrendiklerini sınıftan bir grup öğrenciyle tartışmak için sık sık zaman ayırmayı içerir ( Pintrich ve De Groot, 1990).

Öğrencilerin görüşlerinden bazı öğrencilerin arkadaştan öğrenme koduna; daha iyi anlamak, anlamadığı yerlerin farkına varmak, zaman kaybı ve dikkat dağınıklığı yaratmamak için özellikle bilinçli olarak başvurdukları anlaşılmıştır.

Öğrencilerin hepsi arkadaştan öğrenme kodu altında görüş belirtmiş olup, 1.sınıf öğrencilerinden Eda çalışacağı kişiyi şu şekilde belirlediğini açıklamıştır;

...genelde o derste sinıfta kimin başarılı olduğunu düşünüyoruz. Benden daha iyi de olabilir benle eş de olabilir. Onlardan yardım almak çok güzel. Biraz önce de söylemiştim yapamadiğım şeyler olduğunda hocaya soruyorum. Eğer öyle bir imkânım yoksa ilk başta arkadaşlarımızla paylaşıyoruz. Yani herkes öyle, çünkü sınıfimızda da öyle bir ortam var.

3.sinıf öğrencilerinden Murat ise;

... Daha çok matematiğe arkadaşlarımla beraber çalışırız. Birbirimize anlamadı̆̆ımız noktaları sorarız. Anlamlandırmayla yani daha önceki bilgilerimize yönelik, onlardan bir şeyler çıkarmaya çalışırız.

şeklinde görüşünü belirtmiş, 1.sınıf öğrencilerinden Mehmet ise;

... Genelde yurtta olmanın avantajlyla arkadaşlardan faydalanıyorum.

ifadesi ile bunu avantaj olarak gördüğünü ifade etmiştir.3.sinıf öğrencilerinden Nurgül ise arkadaştan öğrenmenin farklı bir yönüne aşağıdaki gibi dikkat çekmiştir.

... grup olarak çalışmayı da seviyorum ben. Beyin firtınası derler ya birbirlerinden yardım almak ya da ben çözmüşümdür çok mantıklı gelmemiştir sonucu. O şekilde grup halinde çalışınca daha kalıcı oluyor bende. Çünkü herkesin farkl bir fikri oluyor. Belki benim fikrimden daha mantıkl geliyor o kişinin fikri. O yüzden daha oturuyor kafama yani grup halinde çalışmak da yaptığım şeylerden biri ders çalışırken. 
Öğrencilerinden bir kısmı da gerekli olmadı ̆̆ sürece arkadaştan öğrenmeye başvurmadıklarını ifade etmişlerdir. $\mathrm{Bu}$ duruma dâhil olan öğrencilerden biri de 2.sınıf öğrencilerinden Mustafa'dır.

...Takıldiğımız noktalarda veya çözemediğimiz sorularda grup olarak nasıl yapabiliriz diye yardımlaşıyoruz fakat onun dışında bireysel çalışmayı tercih ediyorum.

4.sınıf öğrencilerinden Ufuk, Hülya ve Özlem bu konudaki görüşlerini aşağıdaki şekilde ifade etmişlerdir.

...Genellikle arkadaşlarımızla oturup anlamadı̆̆ım yerleri onlara anlattırtyorum ya da bildiğim halde onlara da isteyerek ders anlatıyorum $\mathrm{ki}$ anlattı̆ı̆ zaman daha iyi öğrendiğimi düşünüyorum. $O$ yüzden arkadaşlarımla sürekli etkileşim içerisinde olmaya önem gösteriyorum.

...onun dışında klz kardeşime anlatıyorum. O anlamasa da anlamış gibi yap diyorum kafa salla falan. Öyle bir tekniğim var o kadar.

...Tek başıma çalıştı̆̆ım zaman anlamadı̆̆ım yerlerde çok fazla zaman kaybediyorum. Hem de dikkatim dağlliyor. Bilen bir arkadaş anlattı̆ğ zaman hemen neyin nerden geldiğini anllyorsunuz.

Zaman ve Çalışma Çevresinin Düzenlenmesi: Zaman ve çalışma çevresinin düzenlenmesi; öğrencilerin genellikle yoğunlaşabileceği yerlerde ders çalışmaları, ders için zamanlarını iyi kullanmaları, bir çalışma programına bağlı kalmakta zorlanmaları, derslerin haftalık okumalarını ve ödevlerini takip ettiklerinden emin olmaları, derslere düzenli olarak devam etmeleri, diğer etkinlikler nedeniyle o derse çok fazla zaman ayıramadıklarını sık sık fark etmeleri, sınavdan önce ders ile ilgili notlarını ya da okumalarını gözden geçirmek için zaman bulmakta zorluk çekmeleri ile ilgili düşüncelerini içerir (Pintrich ve De Groot, 1990).

$\mathrm{Bu}$ konuda görüş belirten öğrenciler, çalışma çevresi konusunda öncelikle yurt ve ev ayrımı yapmaktadır. Öğrencilerin bir kısmı yurdu kalabalık oluşundan, kişisel ihtiyaçlarına olanak tanınmamasından, istenilen her an sessizliğin sağlanamamasından dolayı olumsuz bir çalışma çevresi olarak düşünmektedir. Bu konuda aynı fikri paylaşan öğrencilerden 1.sınıf öğrencisi Mehmet,

... Ben genelde evdeyken ışı̆̆ kapatıp masamdaki lambayla çalışırım. Yurt ortamı işte; ses gürültü olduğu için sınavın son akşamı gece 12 den sonra en iyi çalışma ortamı oluyor. Ben yatılı okudum bizimde etütlerimiz vardl. Program halinde işliyorduk. Burada böyle ortam müsait olunca çalışıyorsun, gece uygun gelmediyse çalışlyorsun. Yoksa öyle ben plan yapayım, asayım, yapayım falan yok. 


\section{2.sınıf öğrencisi Burcu;}

...Hocam genelde erken yatıyorum gece kalkıyorum iki üç gibi.Çünkü ancak o saatlerde sessizliği buluyorum.

ve önce yurtta kalan ve daha sonra eve çıkan 3.sınıf öğrencisi Emel;

...Yurttayken daha çok etkiliyordu. Çok kalabalıktık çünkü. Çok fazla arkadaşım vardl. Yani etkiliyordu. Çoğu zaman çalışmıyordum.

şeklinde görüşlerini belirtmişlerdir.

Yurt ortamının olumsuz bir çalışma çevresi olduğunu düşündüğü halde bundan rahatsız olmayan öğrencilerden biri olan 4.sınıf öğrencisi Ufuk görüşünü şöyle ifade etmektedir;

...zaten kredi yurtlarda kaldı̆̆ım için orda ortamda iyi değildi. Yine müziğimi açardım, yatağa uzanırdım, notları elime alırdım, okurdum. Sonra ĕger böyle iyi anlayamadiğım yerler olursa ĕger, orayı kesinlikle öğrenmem gerekiyorsa mesela teoremleri, onlar gidip sessiz ortamda yazarak çalışırdım.

Bazı öğrencilerde arkadaşlarının kendilerini olumlu yönde güdülediklerini böylece motivasyonlarının yüksek olduğunu belirtmektedir.3.sınıf öğrencisi Nurgül;

...kesinlikle çevre; mesela yurtta kaliyorum ben. Odamda oturduğum zaman arkadaşlarım ders çalıştığı zaman hani onlar beni bir şekilde motive ediyor, hadi sen de gel bize katıl. Ya da canım sikıldığı zaman hani yapacak bir şey bulamadiğım zaman neden ders çalışmıyorum neden boş oturuyorum diyorum kendi kendime.

biçiminde görüş bildirmiştir. Öğrenciler zaman planlanmasında da sınav konusuna dikkat çekmişlerdir.3.sınıf öğrencilerinden Nurgül;

...sinava hazırlanırken bir gün öncesine birakmayı sevmiyorum ben. Hani şey konuları bölüyorum mesela. Üç ünite işlemişizdir. Üçe bölüyorum. Mesela her gün bir üniteye çalışıyorum.

derken, 4.sınıf öğrencilerinden Hülya;

...yani 15 dakika şunu çalışacağım 15 dakika ara vereceğim 15 dakika şunu çalışacağım diye hiçbir zaman çalışmadım. Günlük vardır benim listemde bugün eğitimle tarih çalışacağım mesela onu çalışırım bu akşam. Zamanim ne kadar yeterse ne kadar aylrabilirsem.

demiş, 2.sınıf öğrencilerinden Burcu ise; 
...Konuları açıklamaya çalışırım kendimce. Problemleri çözerim kitaptaki. Ondan sonra geçerim o konuyu. Anlamışımdır büyük ihtimalle geçtiğim zaman. Yarın zaten hazır giderim daha anlayışlı, daha kalıcı oluyor. Böylece sırf sınav zamanı değil sinav zamanı gelmeden de yaparım bu işleri.

biçiminde yanıt vermiştir.

Çaba Düzenleme: Çaba düzenleme; derse çalışırken sık sık sıkılmayı ve yapmayı planlananları bitirmeden önce çalışmayı bırakmayı, derste yapilanlardan hoşlanılmasa bile başarılı olmak için çok çalışmayı, dersin konuları zor olduğunda ya bırakmayı ya da sadece kolay kisımlarına çalışmayı, ders konuları ilgi çekmese ve sıkıcı olsa bile konuyu bitirene kadar çalışmayı başarmayı içerir (Pintrich ve De Groot, 1990).

Çaba düzenleme konusunda görüş belirten 2.sınıf öğrencisi Murat;

...ben mesela ögretmenlik yerine yüksek lisans düşünüyorum. O yüzden alan derslerini aslinda o kadar sevmesem de, bazen nefret etsem de, çalışmam gerektiğini düşünüyorum.

derken akademik kariyer düşünmesinin çabasına etkisine, 3.sınıf öğrencilerinden Nurgül;

...Hani yapmalıyım çünkü ben öğrenciyim, benim görevim ders çalışıp sinıfimı geçmektir. Nihal;

şeklindeki düşüncesini kabullenilen statüye, 1.sınıf öğrencilerinden

...önceki sınavınız kötü geçmişse ikinci sınavınıza çalışmanıza etkiler bence bu. Hani ya daha fazla çalışırsınız daha fazla üzerine yoğunlaşırsınız benim ilk sinavım kötü geçti buna daha fazla çalışmalıyım ya da dersiniz ki ilk sinavim kötü geçti zaten hani bundan sonra çok fazla bir kurtarma şansim yoktur diye dersiniz o etkileyebilir bence çalışmanızı hatta çok fazla etkiler hani kafanızı kurcalar.

ise önceki çalı̧̧maların sonraki çalışmalarına dolayısıyla çabasına etkisine dikkat çekmiştir.4.sınıf öğrencilerinden Özlem ise,

...Ben ders başında çok uzun süre oturamıyorum. Fazla oturduğum zaman sıkllyyorum. Bunu son iki yıldır düzenlemeye çalışıyorum. Önceleri sikılıyorum diye hemen dersi bırakıp çekip gidiyordum. Şimdi düzenimi daha iyi oturttuğumu düşünüyorum. Ders çalışlyorken sikıldiysam kalkıyorum biraz tv izliyorum veya internete giriyorum ama sonra tekrar gelip dersin başına oturuyorum.

görüşü ile zaman içerisinde çabasını kontrol altına almayı başardığını belirtmiştir. 
Kritik Düşünme: Kritik düşünme; öğrencilerin kendilerini s1k s1k derste duyduklarını ya da okuduklarını inandırıcı bulup bulmadıklarını sorgularken bulmay1, derste okunulan ya da kitapta okunulan bir kuram, yorum ya da sonucu destekleyen güçlü kanıtlar olup olmadı̆̆ına karar vermeye çalışmayı, ders konularını başlangıç noktası olarak ele almayı ve onun hakkında kendi düşüncelerini geliştirmeye çalışmayı, derste öğrenilenlerle ilgili kendi düşüncelerini geliştirmeye çalışmayı ve derste ne zaman bir önerme, sonuç okunulsa veya duyulsa olası seçenekler üzerinde düşünmeyi içermektedir (Pintrich ve De Groot, 1990).

Kritik düşünme üzerinde az görüş belirtilen kodlar arasındadır. Öğrenciler bu kod kapsamı içinde daha çok üniversite müfredatını lise müfredatı ile karşılaştırarak sorgulamışlardır. Öğrenciler yükseköğretimde derslerin sayılarını, kredilerini, yoğunluklarını az bulduklarını; fakat buna rağmen derslerin konularını çalışmada, sınavlara hazırlanmakta zorluk çektiklerinden bahsetmişlerdir. Bu konuda 3.sınıf öğrencilerinden İpek,

...Mesela ben üniversiteye geldiğimde tüm ÖSS biyolojisini bir gece de çalıştım. ÖSS ye hazırlanıyorken bir yıl boyunca biyoloji çalıştık bitiremedik. Ama burada bilmiyorum artık üniversiteliyiz kapasitem var demek ki gelmişim bir de biliyorum. Bir gecede bütün biyolojiyi çalıştığımı biliyorum. Galiba üniversiteye gelince kendime güvenim arttl, yapamayacağım şeyleri bile yapıyorum.

derken, 4.sınıf öğrencilerinden Hülya;

...bir dönemde 15 ders vardl, burada 5 ders var. Düşünüyorum 15 dersin yazılısını nereye sıkıştırıyorduk. Şimdi, 5 dersin sinaviyla uğraşamiyoruz.

şeklinde görüşünü belirtmiştir.4.sınıf öğrencilerinden Tolga;

... Yani mesela şunu hissediyorum, okulda derste anlatılanlar yeterli değil. Yani ben bunlarla kalırsam sinırlı bir bilgim olacak. Onu düşündügü̈m için yani değişik kaynaklardan çalışma gereğini de duyuyorum. Daha sonra hocalarımın da mesela şunu demesi, artık sadece okul dersleriyle yetinme farklı kaynaklardan çalış. Araştırmalar yap, oku. Gerçekten bunlar da, bunları duydukça merakım da artıyor. Bunu yapmam gerektiğini de düşünüyorum. Çünkü hep şunu söylüyorlar. Yani üniversitelerde sadece üniversite de verilenle yetinirsen sinırl bir birey olursun. Ama üniversite nedir? Araştırmadır, kendi çabaların. Bunu yaparsan farklı kaynaklardan yararlanırsan, daha çok okursan gerçekten de insanın düşünme yeteneği, kabiliyeti gelişiyor. 
ifadesi ile üniversitenin anlamını tekrar sorgulamıştır. Üniversite müfredatındaki değişiklik de öğrenciler tarafından sorgulanmış, müfredatın sürekli değiştirildiği ifade edilmiş, bazı derslerin kaldırılmasının sebebi gereksiz olmasıysa neden önceki devrelerin işlediği merak edilmiștir.

\section{Motivasyonel İnançlar}

Motivasyon bölümü, öğrencilerin ders için görev ve amaç inanışlarını, bir dersi başarmak için yetenekleri hakkındaki inanışlarını ve bir dersin sınavı hakkındaki kaygılarını içerir. Motivasyonel inançlar bölümünü oluşturan boyutlar aşağıda Şema 2'de gösterilmiştir.

Şema 2 Motivasyonel İnançlar Modeli

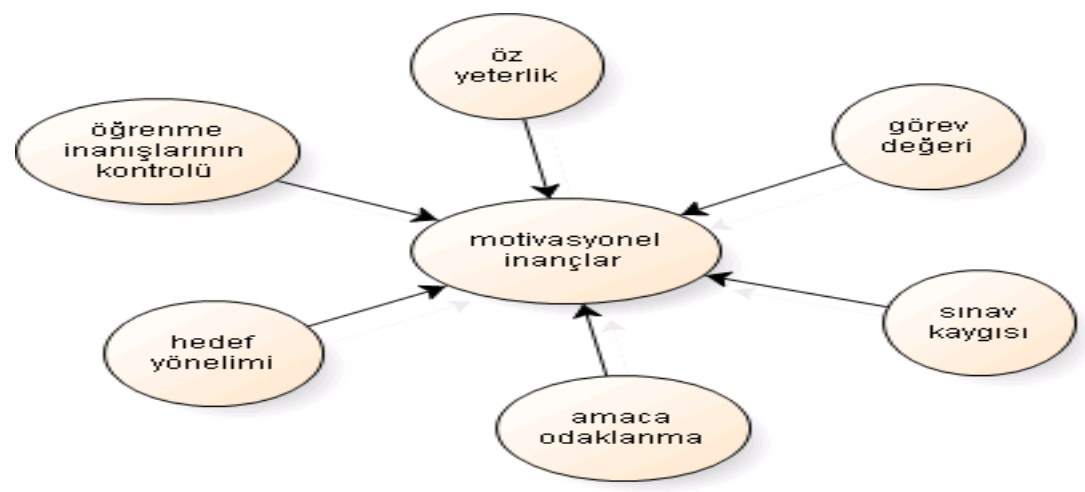

Öğrenme stratejilerini oluşturan boyutlarla ilgili öğrencilerin vermiş oldukları görüşlerin sayısı ise Tablo 4'te gösterilmiştir.

Tablo 4 Cinsiyet ve Sınıf Değişkenine Göre Motivasyonel İnançları Oluşturan Boyutlara İlişkin Frekans Tablosu

\begin{tabular}{lllllll}
\hline & Erkek & Kiz & 1.sinıf & 2.sinıf & 3. sinıf & 4.sinıf \\
\hline Amaca Odaklanma & 5 & 5 & 2 & 2 & 3 & 3 \\
Hedef Yönelimi & 1 & 2 & 0 & 1 & 1 & 1 \\
Görev Değeri & 1 & 2 & 0 & 1 & 1 & 1 \\
Öğrenme İ. Kon. & 7 & 7 & 3 & 4 & 3 & 4 \\
Öz Yeterlik & 6 & 6 & 2 & 2 & 4 & 4 \\
Sinav Kaygisı & 9 & 8 & 2 & 5 & 5 & 5 \\
\hline
\end{tabular}

Tablo 4 incelendiğinde öğrenme stratejilerini oluşturan alt boyutlarda en çok görüş belirtilen kavramın sınav kaygısı boyutu, en az görüş belirtilen kavramın ise hedef yönelimi ve görev değeri boyutları olduğu söylenebilir. Tablo 4'e göre kızların ve erkeklerin belirttiği görüş sayısı motivasyonal inançlar boyutunda da hemen hemen eşittir. 
Amaca Odaklanma: Amaca odaklanma; derste iyi bir not almanın kişiyi en çok memnun eden şey olmasını, genel not ortalamasını yükseltmenin kişi için çok önemli olduğundan dersten iyi bir not almak istemeyi, derste diğer öğrencilerin çoğundan daha iyi notlar almak istemeyi ve derste öğrencinin yeteneklerini ailesine, arkadaşlarına ve başkalarına göstermek için başarılı olmak istemesini içerir (Pintrich ve De Groot, 1990). Kapsamından da anlaşılacağ 1 üzere amaca odaklanmada daha çok dersten alınan puanlandırmalar üzerinde durulmakta ve öğrencinin kendini ispatlama isteğini taşımaktadır. Öğrenciler amaçlarına ne kadar çok odaklanırlarsa, hedeflerini başarmak için o kadar ısrarcı olacaklar ve dolayısıyla iyi de bir öz-düzenleyici olacaklardır.

Amaca odaklanma konusunda öğrencilerin genel olarak üzerinde durduğu konu, başarılı olmak istemeleri ve bunun için ders çalışmalarıdır. Öğrencilerin bir kısmı amacına kendi iç çabaları ile odaklanırken kimi ise arkadaşlarının ve ailelerinin destekleri ile amaçlarına odaklandıklarını söylemiş̧lerdir. Aile ve arkadaş desteğini yanına alan öğrencilerden 3.sınıf ögrencisi Murat bu düşüncesini;

...ablamın kazanmamda etkisi çoktu, o yüzden onun istediğini yapmam gerekiyordu, ama seviyorum matematiği. O yüzden o sürekli bana destek olur. Arkadaşlarım da sen yaparsın 15, 20 de alsan sen o sinavi geçersin der. Belki o gazla mi diyeyim kendime güvenmem ve rahatlamam sayesinde olduğunu düşünüyorum. Ders birakmam. Geçen seneki dersi birakmamın sebebi de ortalamamı yükseltmek için yaz okuluna gitmeyi göze almamdı.

şeklinde ifade ederken 1.sınıf öğrencilerinden Nihal hedefine sıkı sıkıya bağlanmasını,

...Insan hedefini belirlemişse ona doğru gidiyorsa yani onun için her şeyi yapmayı göze almuştır zaten. Ben kendime bir hedef koymuşsam, ona ulaşacağım diyorsam, bütün zorluklar bana artık çok zor görünmez gözünüze. Sonuçta göze almışsınız, ben oraya ulaşacağım diyorsunuz.

ile, 2.sınıf öğrencilerinden Burcu ise;

...başarısızlı̆̆ı kolay kolay kabul edecek biri değilim. Sinavın kötü geçtiyse, genelde yurda gidip ağlarım. Başarmak zorundayım çünkü çalışlyorsam sonucunu da görmek isterim. Arkadaşlarım dalga geçerler bu yaşta da ağlanılır mı diye. Ama başarısızlık yoktur benim için, başarmak zorundayımdir.

şeklinde düşüncesini ifade etmiştir. Aileyi öğrencilerin çoğu destek olarak görürken 3.sınıf öğrencilerinden İpek'in; 
...bir istatistik sınavım iyi değildi. Ailenin ilk çocuktan başarısı beklentisi yüksek olur ya. Ben ailemin ilk çocuğuyum, bir şeyi yapamayacă̆ıma inanmıyorlar. İstatistiğim kötüydü hala babama diyemedim, baba ben bu dersten sorumlu geçtim diyemedim.

yukarıdaki cümlelerinden; öğrencinin ailesinin destek olmadığını söyleyememekle beraber, ilk çocuk olmanın ağırlığını taşıdığını ve bu ağırlığın onu amacına odaklayan sebeplerden biri olduğu düşünülebilir.

Hedef Yönelimi: Hedef yönelimi; derste yer alan konuların öğrencileri yeni şeyler öğrenmeye teşvik etmesini istemesini, derste öğrenilmesi zor bile olsa meraklarını uyandıran konuları öğrenmek istemelerini, dersin en tatmin edici yanının konuları mümkün olduğunca tam anlamaya çalışmak olduğunu düşünmelerini ve derslerde firsat olduğu zaman iyi bir notu garantilemese de öğrencinin öğrenmesini sağlayacak ödevler seçmesini içerir (Pintrich ve De Groot, 1990). Hedef yönelimi daha çok kişinin kendini geliştirmeye yine kendisinin istek duymasıyla ilişkilidir. $\mathrm{Bu}$ isteği oluşturan güdü; bilmeme ihtiyacından doğabileceği gibi, daha çok bilmek istemekten, meraktan ve araştırma ihtiyacından da doğabilir.

Hedef yönelimi, hakkında en az görüş belirtilen iki alt boyuttan biridir. Hedef yönelimi kodunun içeriğindeki ifadelerin biraz daha mükemmeliyetçiliği gerektirmesi, bu kodun öğrenciler tarafindan az görüş belirtilen kod olmasını sağlamış olabilir.3.sınıf öğrencilerinde Hatice;

...Ama diyorum ki acaba ne kadar öğrendim ben bu dersi. Bunlar bana lazım ben ilerde bir matematik ögretmeni olacaksam bu bilgiler bana lazım. Acaba ben bunun ne kadarını ögrendim. .Bu yüzden de ister istemez araştırmaya yöneliyorsunuz. İşte bir şeyleri öğrenmem lazım ki kendimi geliştirmem lazım psikolojisi oluyor insanda.

diyerek hedefini sorgulamaya başladığını belirtmiştir.

Görev Değeri: Görev değeri de üzerinde en az görüş belirtilen diğer alt boyuttur. İçeriğini; öğrencinin derste öğrendiklerini diğer derslerde de kullanabileceğini düşünmesi, dersin konularını öğrenmenin öğrenci için en önemli şey olması, öğrencinin dersin içerdiği konularla çok ilgilenmesi, konuları sevmesi ve o konularını öğrenmenin kendi için yararlı olduğunu düşünmesi ve dersin içeriğini anlamanın kendi açısından önem arz etmesi oluşturur (Pintrich ve De Groot, 1990). 
1.sınıf öğrencilerinden Nihal bu konudaki görüşünü;

...Dediğim gibi, matematikle geometriyi örgütleyebiliriz, onlart birleştirebiliriz. Matematiği birçok dersle birleştirebiliriz, bağlantı kurabiliriz. Mesela matematik olmadan fiziği anlayamazsınız, belli bir yere kadar gelemezsiniz. Kimya da ayn şekilde ama bir kimya olmadan matematik çözebilirsiniz diye düşünüyorum.

ile ifade etmiştir.

Öğrenme İnanışlarının Kontrolü: Bu kavram kişinin öğrenmesinden ya da öğrenememesinden kimi ya da neyi sorumlu tuttuğu ile ilişkilidir. Genel olarak; uygun biçimde çalışırsam bu dersteki konuları öğrenebilirim, bu dersteki konuları öğrenemiyorsam bu benim hatamdır, yeterince sıkı çalışırsam ders konularını öğrenebilirim ve eğer ders konularını anlamadıysam bu yeterince sıkı çalışmadığım gibi inanışları içine alır (Pintrich ve De Groot, 1990).

Öğrencilerin hepsi bu konuda görüş belirtmiş olup bu görüşlerden; öğrencilerin öğrenme inanışları hakkında bilinçli oldukları ve başarısızlık sebeplerini yeterince çalışamamaları, düzenli çalışamamaları, yeterince soru çözememeleri ve stres, kaygı gibi faktörlere bağladıkları anlaşılmıştır. Aslında bu noktada bir içsel yükleme de söz konusudur. Çünkü öğrenciler karşı karşıya kaldıkları durumun nedenlerini, kendileri ve kendi özellikleri olarak görmüşlerdir.3.sınıf öğrencilerinden İpek bu konuya şöyle bir bakış açısı getirmiştir;

...ben sınavda başarısız olursam kendimi kurtarmak için düşünürüm ki acaba hocadan $\mathrm{ml}$ diye. Sonra hocaya haksıllk etmemem gerektiğini anllyorum. Çünkü o sinavi yapanlarda var. Hocanın yüzünden olsaydı onlarda yapamazdl. Ayn siniftaysak kapasitemiz de hemen hemen aynidır. Hoca herkese o dersi anlatiyor. Yani ben sinavda başarisiz olursam bahaneyi kendime de bulurum. Daha çok çalışsaydım diye. Daha çok soru çözseydim diye şunu da yapsaydım diye.

Öz Yeterlik: Sosyo bilişsel teorinin anahtar kavramlarından biri olan öz yeterlik; bireyin belli bir performansı göstermek için gerekli etkinlikleri organize edip başarılı olarak yapma kapasitesine ilişkin kendi yargısıdır (Bandura, 1986). Öz yeterliğin öz-düzenlemeyle ilgili yanı şudur: kişilerin öz yeterlik inanışları, amaç oluşturma, öz-izleme, öz değerlendirme ve strateji kullanımı gibi öz-düzenleyici süreçlerin kullanımı boyunca kişinin öğrenmesine motivasyon mantığı ile katkıda bulunur (Zimmerman, 2000).

Öz yeterlik; öğrencinin dersten çok iyi bir not alacağına inanmasını, derste yer alan kitap, dergi, makale... vb. de yer alan en zor konuları 
anlayabileceğinden emin olmasını, derste öğretilen temel kavramları öğrenebileceğinden emin olmasını, derste öğretmen tarafindan sunulan en karmaşık konuları anlayabileceğinden emin olmasını, dersten başarılı olmayı beklemesini, derste öğretilmekte olan becerilerde uzmanlaşabileceğinden emin olmasını ve dersin zorluğunu, dersin öğreticisini ve kendi becerilerini göz önüne alındığında derste iyi olacağını düşünmeyi içerir (Pintrich ve De Groot, 1990). Bu kod ile ilgili görüşmelerden anlaşılmıştır ki öğrenciler yüksek öz yeterlik algısına sahiplerdir. Öğrencilerin çoğu başarılı olacakları konusunda kendilerine güvendiklerini ve bunu da düzenli ders çalışma ile sağladıklarını söylemişlerdir.2.sınıf öğrencilerinden Mustafa;

...Ben başarısızlığ ve başarıyı yaşadım. Düzenli çalışmanın başarı için yeterli olduğunu gördüm. Fakat şimdi sınavlar benim için sorun değil, şimdi bile analiz sinavina girebilirim.

ifadesi ile öz-yeterlik algısının ne kadar yüksek olduğunu ortaya koymuş̧tur. Sınav konusunda 2.sınıf öğrencilerinden Burcu;

...Sınavlardan sonra genelde ne alacă̆ımı bilirim ben düşük mü yüksek mi alacă̆ımı.

derken 3.sınıf öğrencisi Harun;

...Normalde ben son güne bırakıp çalışırım yine de başarırım.

ifadesi ile öz yeterliğinin ne kadar yüksek olduğunu ortaya koymuştur. Yine 1.sınıf öğrencilerinden Nihal ise öz yeterliğinin yüksek oluşundaki sebebi şöyle ifade etmiştir:

...Hani şey derler ya başarı basamaklarını kimse elleri arkasında tırmanmaz diye. Çok doğru aslında hani her şeyi göze almanız gerekiyor. Zorluklar da var, güzellikler de. Bunun bilincinde olduktan sonra her şeyin üstesinden gelirsiniz diye düşünüyorum. Hiçbir şey sizi yıldırmaz...

3.sınıf öğrencilerinden Hatice ise aşağıdaki ifadesi ile dersten önce çalışmanın öz yeterliği düşürücü olduğunu söylemiş ve şöyle örneklendirmiştir;

... Bence hocam saylsal derslere gelmeden önce ders çallşmak zararl, yani yararından daha fazla zararı var. Çünkü işte arkadaşın söylediği gibi bilinmeyen terimler var, onlart ne olduğunu bilmiyorsunuz. Sonradan bağlantı kuramıyorsunuz onların arasında ve mesela akademik özgüven denilen şey var ya insanda onu yok ediyor bence. Çünkü bilmediğiniz şeyleri kendiniz öğrenmeye çalışırken zorlanıyorsunuz. Bu sefer sanki ben bunu hiç öğrenemeyecekmişim gibi bir şey oluşuyor insanın içinde. 
Sınav Kaygısı: Sınav kaygısı; öğrencilerin öğrenim hayatları boyunca yaşadığı en büyük kaygılardan biridir. Bu kaygıyı bazı öğrenciler zamanla aşmalarına rağmen bazıları ise üniversiteye de taşımışlardır. Literatürde kayg1, öğrenmeyi etkileyen faktörlerden öğrenen ile ilgili bir değişken olup, çok düşük ve çok yüksek kaygı düzeyleri öğrenmeyi zorlaştırırken orta düzeyde bir kaygı duymanın öğrenmeyi kolaylaştıracağı ve teşvik edeceği açıklanmaktadır (Bacanlı, 2003).

Sınav kaygısı; öğrencinin sınavlara girildiğinde başarısızlığının getireceği sonuçları düşünmesini, sınava girdiğinde kendini sıkıntılı ve tedirgin hissetmesini, sınava girdiğinde kalbinin hızla çarptığını hissetmesini, sınav sırasında cevaplayamadığı diğer soruları düşünmesini ve sınavlara girdiğinde başarısızlığının getireceği sonuçları düşünmesini içerir (Pintrich ve De Groot, 1990 ).

Yapılan görüşmelerden anlaşılmıştır ki; öğrencilerin sınavlara çalışırken sınava girecekleri dersin konularını tam olarak çalışmış olmaları kaygılarını düşürücü rol oynarken, konuları tam olarak bitirememeleri de kaygiyı arttırıc1 rol oynamaktadır. Kaygıyı arttırıcı diğer bir etken ise, genel not ortalamasını yükseltme isteğidir. Bunu 4.sınıf öğrencilerinden Özlem şöyle anlatmaktadir;

... Bu biraz bilgiyle alakalı bir şey; ne kadar çok fazla şey biliyorsanız o kadar kaygınız düşük oluyor. Yani eğer ben çok çalışarak giriyorsam o sinava çok stresli girmiyorum, yani rahat giriyorum Evet sinavda çıkacağının sıkıntısı var ama çok fazla kaygıyla girmiyorum. Bir de çok fazla not illa çok yüksek not almalıyım kaygısı da yok. O not kaygısı da çok önemli bir şey sanırım. Onun da olmadığ i için çok fazla stresli girmiyorum ama eğer bilgi düzeyim düşükse ve gerçekten kendimi hazır hissetmiyorsam orda stresli giriyorum.

Ayrıca 3.sınıf öğrencisi Harun'un,

...hocam sınav endişesi pek olmuyor da özellikle arkadaşımızın dediği gibi yurtta diğer arkadaşlar önceden ders çalışmaya başllyorlar. Dolayısıyla bu da beni biraz endişelendiriyor. Yani şunu düşünüyorum bu kadar zor mu ki bir hafta çalışlyorlar, bu beni olumsuz yönde etkiliyor kaygılandırıyor.

şeklindeki ifadesinden de anlaşıldığı gibi öğrenciler arkadaşlarının sınavdan önce çalışmaya başlamalarından da kaygıya kapılabilmektedirler.4.sınıf öğrencisi Hülya, sınav stresi yaşamayan öğrencilerden olup bunu aşağıdaki alıntıda da görüldüğü gibi kendi geliştirdiği stresle başa çıkma yollarını bularak yendiğini ifade etmiş̧tir; 
...Artık siradan bir şey oldu sınavlar benim için. Sinavda çıkan soruları sinavdan önce çözüp sinavda çözemiyorsam bir sorunum olmall dedim. Sinavda çözebildiğim zamanla çözemediğim zaman arasındaki farkı kavradım. Neymiş? Iște en ön sirada oturmuyorum mesela. En ön sirada oturduğum zaman hocanın kâğıdıma bakması beni stres yapıyor, acaba yanlış mi yapıyorum diye. O yüzden arkada oturmaya gayret ediyorum, yani biraz rahat oluyorum. Sinavdan önce ne yapacağım ne edeceğim diye düşünmüyorum. Giriyorum çıkıyorum.

Bazı öğrenciler için ise sınav kaygılarının başlıca sebebi aileleridir. Okudukları bölümde yaz okulu uygulamasının olması ve sınavlarda başarısız olurlarsa yaz okuluna gitme ihtiyac1 duyacakları ve bunun da maddi bir külfet gerektirmesi kaygıyı etkilemektedir. 1.sınıf öğrencilerinden Mehmet bu düşüncesini şöyle ifade etmiştir;

...bende de aile tarafindan sikıntı var. Yaz okuluna kalırım derdi var. Çok para gidiyor. Mesela benim ăgabeyimde üniversite de okuyor. Geçen sene birinci sinıfta bir dersten kaldı diye bir yaz boyunca işkence oldu. O bir dersten kaldı diye babam bir yaz boyunca işkence etti ona işte, sen böyle yaptın şöyle yaptın diye.

Sınav kaygısı yaşamayan ve bunu ailesinden aldığı destekle sağlayan Murat ise;

... ben sinavda zaylf alınca diyorum ya bir rahatllk var yani. Babam săg olsun, geçen sene yaz okuluna gitmiştim, bu sene de gitme durumum var gibi. 1-2 DD dersim var onları alayım dedim. Yalnız babam dalga geçiyor geçen sene İzmir'e gitmiştin bu sene de Ankara'ya git gezmiş olursun diyor. Biraz ă̆ırıma gidiyor o yüzden çalışıyorum. Başarısı olunca çok üzülmüyorum.

şeklinde görüş belirtmiştir. Öğrencilerin bir kısmı ise sınav streslerinin dersten derse değiştiğini ifade etmiştir.2.sınıf öğrencilerinden Zeynep;

...mesela Analizde daha az stres yapıyorum. Yapacağım kendime daha güvenim var çünkü o konu da daha iyiyim gibi geliyor. Ama Lineer Cebiri daha önce pek fazla görmediğim için ilk sinavina gireceğim zaman örneğin sorulardan ne çıkacağını nasıl sorulacă̆ını bilediğimden, Analize göre daha çok strese giriyorum.

ifadesi ile iyi olduğu derslerde yapabileceği konusunda kendisine güvendiği için kaygısını da minimum düzeyde yaşadığını belirtmiştir. 


\section{TARTIŞMA VE YORUM}

Günümüz öğrenme yaklaşımlarının temelini oluşturan ve öğrenciyi merkeze alan aktif (etkin) öğrenme yaklaşımlarının üzerinde durduğu özdüzenleyici öğreniciler, kendi öğrenme süreçlerinde meta-bilişsel, bilişsel ve davranışsal olarak aktif olan öğrenicilerdir (Zimmerman, 1986).Özdüzenleme üzerinde çalışan araştırmacılar öz-düzenlemeyi, öğrenme stratejileri ve motivasyon bölümü olarak iki kısımda incelemişlerdir. Bu çerçeve, motivasyon ve öğrenme stratejileri bölümlerinin öğrenicinin kişisel özellikleriyle sabit kalmaktan ziyade, motivasyonun dinamik olduğunu ve sınırlarının arttırılabileceğini ve öğrenme stratejilerinin de öğrencinin kontrolü altında alınabileceği ve öğrenilebileceğini kabul eder (Anthony ve Artino, 2005).

Bulgular bölümündeki Tablo 3'ten anlaşılacağı üzere; öğrenme stratejileri kategorisinde en çok adı geçen/kullanılan alt boyutu bilişüstü özdüzenleme ve zaman/çalışma çevresinin düzenlenmesi stratejileri oluşturmuştur. Bunu tekrarlama ve ayrıntılandırma alt boyutları takip etmektedir. Arkadaştan öğrenme, örgütleme ve yardım arama, kritik düşünme ve çaba düzenleme üzerinde durulan diğer alt boyutlar arasındadır. Yükseköğretimde öğrenme stratejileri bölümü öğrenciler tarafindan aktif bir şekilde uygulanmakta olup, bilişüstü öz-düzenleme ve zamanın ve çalışma çevresinin kontrolü alt boyutunda görüş belirtenlerin sayısının çok olması, öğrencinin artık kendisinin ve kendi özelliklerinin farkında olmasıyla dolayısıyla iyi bir öz-düzenleyici olmasıyla ilişkilidir.

Motivasyon kategorisinde ise Tablo 4'ten anlaşılacağı üzere en çok görüş belirtilen alt boyut, sınav kaygısıdır. Bunu öğrenme inanışlarının kontrolü, öz yeterlik, amaca odaklanma, hedef yönelimi ve görev değeri takip etmektedir. Öğrenciler motivasyon kategorisini aktif bir şekilde uygulamasına rağmen, hedef yönelimi ve görev değeri alt boyutları ile ilgili görüşlerinden anlaşılmıştır ki öğrenciler araştırma-geliştirme faaliyetlerine yeteri kadar önem vermemektedirler. Yüksek öğretimin öğrencilerden beklediği hedefler düşünüldüğünde bu kod kapsamında çok az görüş belirtilmiştir. $\mathrm{Bu}$ durum ise öğrencilerin iyi bir öz-düzenleyici olma çabalarını kısmen de olsa etkileyecektir Hâlbuki görüşmelerden anlaşılmıştır ki öğrencilerin çoğu üniversiteye başladıkları zaman yüksek derece de özyeterlik duygusuna sahiplerdir. "Kapasitem var ki kazandım" görüşü ile hareket etmişler ve normalden az çaba göstererek başarılı oldukları takdirde bu yolu tercih etmişlerdir. Çoğu öğrenci derste anlatılanı yeterli olarak görmekte ve diğer çalışmalar için yeterli çaba göstermemektedir. 
Yine Tablo 3 ve Tablo 4'ten anlaş1lacağ üzere cinsiyet, bu çalışmada farklılık yaratan bir değişken olarak karşımıza çıkmamıştır. Alan yazında da eldeki çalışmanın bulgularını destekleyen (Wolters ve Pintrich, 1998) ve desteklemeyen (Alc1 ve Altun, 2007; Peklaj ve Pecjak, 2002) farklı araştırmalara rastlanmıştır.

$\mathrm{Bu}$ çalışmada İlköğretim matematik öğretmen adaylarının birer özdüzenleyici olma çabaları ve bu yolda ilerlerken kullandıkları adımlar yansıtılmaya çalışılmıştır. Yapılan görüşme ve odak grup görüşmelerinden öğrencilerin bir kısmının bilinçli bir kısmının ise alışkanlıkları sonucu tekrarlama, ayrıntılandırma, örgüteme, bilişüstü öz-düzenleme, arkadaştan öğrenme, yardım arama gibi öz-düzenleme stratejilerini kullandıkları ve özellikle öğrenme inanışlarının kontrolü, öz yeterlik ve sınav kaygısı gibi konularda ise motivasyonel inançlara sahip oldukları anlaşılmaktadır. Ayrıca öğrenciler sınıf kademeleri arttıkça çalışma taktik ve stratejilerini daha iyi oluşturmakta fakat çalışma çabalarını biraz da olsa yitirmektedirler. Öğrencilerin üniversiteye başlamadan önce üniversite hakkındaki aşırı beklenti, aşırı zorluk gibi düşüncelerini zamanla yitirmeleri, artık az çalışmayla başarıya sahip olma arzusunun ders çalışma hızlarını azaltmalarına sebep olduğu yine yapılan görüşmelerden anlaşılmıştır. Alcı ve Altun (2007) 9, 10 ve 11. Sinıflar ile yaptıkları araştırmada öz düzenleme ve biliş-üstü becerilerinde 9 ve 10. Sinıfların lehine anlamlı bir farklılık ortaya çıkarmışlardır. Bu sonuç eldeki araştırmanın bulgularını desteklemektedir.

Öğrencileri iyi bir öz-düzenleyici olmaya teşvik etmek, iyi bir özdüzenleyici olma yollarının farkına varmasını sağlamak ve öğrencilerin sahip olduğu öz-düzenleme becerilerinden haberdar olmak eğitimi daha nitelikli kılacaktır. Böylece eğitim-öğretim faaliyetleri de daha nitelikli hale gelecek ve içinde bulunduğumuz bilgi çağının ihtiyaç duyduğu özdüzenleyici öğreniciler yetişmeye devam edecektir. Öz-düzenlemeyi öğrenme konusunda ülkemizde ve dünyada birçok araştırma yapılmasına rağmen bu araştırmaların çoğu nicel araştırma yöntemiyle sınırlı kalmıştır. Yapılacak araştırmalarda nitel yöntemlere de yer vermek öz-düzenlemeyi incelemeyi konusuna da yeni bir açılım getirecektir. Öğrencilerin cinsiyet, mezun oldukları lise ve öğrenim görmekte oldukları ana bilim dalı türüne göre öz-düzenleme becerileri açısından farklılık taşıyı taşımadıkları nitel yaklaşımlarla çalışılacak konu alanlarını oluşturabilir. 


\section{KAYNAKLAR}

Anthony, R. ve Artino, Jr. (2005). Review of the Motivated Strategies for Learning Questinnaire.

Alc1, S. ve Altun, S. (2007). Lise Öğrencilerinin Matematik Dersine Yönelik Özdüzenleme ve Bilişüstü Becerileri, Cinsiyete, Sınıfa ve Alanlara Göre Farklılaşmakta mıdır? Çanakkale Üniversitesi Sosyal Bilimler Enstitüsü Dergisi. 16(1), 33-44.

Arrends, R.I. (1979). Classroom Instruction and Management. New York: McGraw-Hill.

Bacanlı, H. (2003). Gelişim ve Öğrenme. Nobel Yayın Dağıtım, Ankara.

Bandura, A., (1977). Social Learning Theory.Englewood Cliffs, NJ:PrenticeHall.

Bogdan, C.R. ve Biklen, S.K. (2007). Qualitative Research for Education ; An Indroduction to Theory and Methods, Pearson, Boston.

Derry, S.J. ve Murphy, D.A. (1986). Designing systems that train learning ability:from theory to practice.Review of Educational Research, 56(1), $1-39$.

Eom, Y., Reiser, R.A. (2000). The effectsof self regulation and instructional control on performance and motivation in computer-based instruction. International Journal of Instructional Media. 27(3), 247-261.

Garcia, T. ve Pintrich, P.R. (1995). Assessing Students' Motivation and Learning Strategies: The Motivated Strategies for Learning Questinnaire. Sayfa Amerikan Eğitimsel Araştırma Kurumunda sunulmuştur. San Francisco.

Peklaj, C. Ve Pecjak, S. (2002). Differences in Students Self-Regulated Learning According to Their Achievement and Sex. Studia Psyhology. 44. 29-43.

Pintrich, PR., De Groot, E.V. (1990).Motivational and Self-regulated Learning Component of Classroom Academic Performance. Journal of Educational Psyhology, 82, 33-40.

Schunk, D.H. (2005). Self-Regulated Learning:The Educational Legacy of Paul R.Pintrich. Educational Psyhologist, 40(2), 85-94.

Senemoğlu, N. (2004). Gelişim Öğrenme ve Öğretim. Gazi Kitabevi, Ankara. 
Üredi, I. Ve Üredi, L. (2005). İlköğretim 8.sınıf Öğrencilerinin ÖzDüzenleme Stratejileri ve Motivasyonel İnançlarının Matematik Başarısını Yordama Gücü. Mersin Üniversitesi Eğitim Fakültesi Dergisi, 1(2), 250-260.

Wolters, A.A. ve Pintrich P.R. (1998). Contextual Differences in Student Motivation and Self-

Regulated Learning in Mathmatics, English and Social Studies Classrooms. Instructional Science. 26. 27-47.

Yıldırım, A. ve Şimşek, H. (2006). Sosyal Bilimlerde Nitel Araştırma Yöntemleri, Seçkin Yayıncılık, Ankara.

Zimmerman, B.J. (1986). Devolopment of a Self Regulated Learning Which are the key subprocesses. Contemporary Educational Psyhology, 16, 307-313.

Zimmermen, B.J. (1989). A Social Cognitive View of Self Regulated Academic Learning. Journal of Educational Psychology, 81(3), 572 663.

Zimmerman, B.J. (2000). Self-Efficacy: An Essential Motive to Learn. Contemporary Educational Psyhology, 25, 82-91.

Zimmerman, B.J. ve Schunk, H.D. (2007). Influencing Children's Self Efficacy and Self Regulation of Reading and Writing Through Modelling. Reading-Writing Querterly, 23(1), 7-25. 
